\title{
実験及び数值サーマルマネキンを用いた \\ 室内環境における人体各部位の対流熱伝達率の測定 \\ MEASUREMENT OF CONVECTIVE HEAT TRANSFER COEFFICIENTS WITH USING AN EXPERIMENTAL AND COMPUTATIONAL THERMAL MANIKIN IN INDOOR ENVIRONMENTS
}

\author{
梁 禎 訓*，加藤 信 介**，林 立也***，村上周 三**** \\ Jeong-Hoon YANG, Shinsuke KATO, Tatsuya HAYASHI \\ and Shuzo MURAKAMI
}

\begin{abstract}
The purpose of this study is to make a database of the local convective heat transfer coefficients $\left(h_{c}\right)$ for each part of a human body in indoor environments. Values of the local $h_{c}$ for a naked human body are determined based on both the results of experiments on a thermal manikin and analyses of the radiative heat transfer rate. The results are followed. (1) At the extreme parts of the human body, $\mathrm{h}_{\mathrm{c}}$ is about $1.5 \mathrm{~W} / \mathrm{m}^{2} \mathrm{~K}$ higher than the average value for the whole body, and for the trunk parts are about $1.0 \mathrm{~W} / \mathrm{m}^{2} \mathrm{~K}$ lower than the average values in the state of standing and sedentary. (2) The value for the local $h_{c}$ decreases as the human body approaches the furniture.
\end{abstract}

Keywords: Convective Heat Transfer Coefficients, Thermal Manikin, Radiation Analysis

対流熱伝達率、サーマルマネキン、放射解析

\section{1. はじめに}

人間が普段居住している建築空間は上下温度差、非対称放射、ド ラフトなどが存在する温熱的には不均一な環境である。また、人体 は各部位に固有の形状的特徵を有しているため、その放熱特性は部 位毎で大きく異なり、温熱不快感を感じる可能性がある。人体の局 所的放熱特性を把握し、その温熱感を評価するため、近年多分割生 理モデル 1), 2)や実人体形状モデルを用いた人体熱放散に関する数值

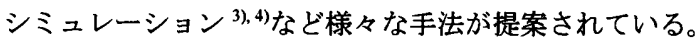

人体の全身及び各部位における対流熱伝達率に関する主な既存の 研究として、李ら ${ }^{5}$ は室内気流が一般的に乱流であることに着目し、

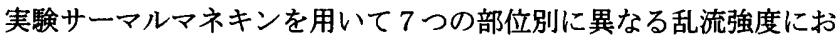
ける対流熱伝達率を測定した。石井ら ${ }^{6}$ は自然対流時の人体全身お よび局所の対流熱伝達率を熱流計を用いた実験により推定した。尾 関ら》は日射環境におけるサーマルマネキン周りの対流熱伝達率を 実験と放射解析により算出した。大黒ら ${ }^{8)}$ ，9 1 は無風時と気流下にお ける人体各部の着衣抵抗及び対流熱伝達率をサーマルマネキンによ り算出した。M.C.G. Silva $ら^{10}$ は $0 \sim 4 \mathrm{~m} / \mathrm{s}$ の風速範囲における風向変 化時の人体各部位の対流熱伝達率をサーマルマネキンの実験により 算出した。
既存の研究の多くは、人体の形状の特性を簡易的人体モデルや人 体形状の異なる他の研究成果に基づき、人体の有効放射面積または

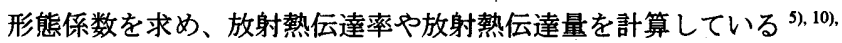
11), 12), 13), 14)。このようにして求められた放射熱伝達量は、顕熱放散量 からこれを差し引いて対流熱伝達量を求め、対流熱伝達率を算出す $3^{5), 10), 13)}$ のに用いられるため、その精度は放射熱伝達量算出の精度 に大きく依存する。しかし、各部位に対する有効放射面積や形態俰 数を詳細に求めて同様に人体の対流熱伝達率を算出している研究 ${ }^{6}$. 7), 8),99は少なく、人体表面での放射熱伝達の分布性状が十分な精度で 評価されていない可能性がある。人体の複雑形状や姿勢の変化など に対して有効放射面積や形態係数を厳密に求めるためには、非常に 詳細な分割による解析が必要となるため、既存の研究では、類似の データを参考することで、多分割生理モデルの解析や温熱環境評価 が行われてきた。また、人体の放射環境に重大な影響を及ぼす近接 する什器などの影響に関しては、現在まで殆ど検討されていない。

一方、CFD を用いて、実人体形状の人体モデルを対象とした対 流・放射連成解析を行うためには、多くの時間と努力が必要となる ため、特に放射解析が必要とされない場合には、対流解析のみ行わ れている。しかし、室内の静稳環境を対象とした既存の研究におい

\footnotetext{
* 東京大学大学院工学系研究科 大学院生・修士 (工学)

** 東京大学生産技術研究所 教授・工博

*** 陎日建設計 工博

**** 慶應義塾大学理工学部 教授・工博
}

Graduate Student, Graduate School of Eng., University of Tokyo, M. Eng. Prof., Faculty of Science and Technology, Keio University, Dr. Eng. Nikken Sekkei Ltd., Dr. Eng.

Prof., Faculty of Science and Technology, Keio University, Dr. Eng. 
ては、対流熱伝達率もしくは対流熱伝達量を類似の研究成果になら い境界条件として与えており、人体の周辺環境もしくは姿勢の変化 に応じた対流熱伝達性状の差異は考慮することが困難であった。

本研究は以上の過去の検討を踏まえ、室内環境における人体部位 別の対流熱伝達率 $\left(h_{c}\right)$ のデータベース作成を目的とする。室内の静 穏気流環境を想定した恒温チャンバーで人体の代わりに裸体の実験 サーマルマネキンを設置し、立位と座位状態において人体各部位の 対流熱伝達率を人体モデルからの顕熱放散量をパラメーターとして 検討する。検討に際しては人体モデルの形状特徴や姿勢などを考慮 した詳細な放射解析を利用する。また、一般のオフィス環境を想定 し、デスクやパーティション、パソコン等の什器が人体各部位の対 流熱伝達率に及ぼす影響を検討する。更に、人体の姿勢変化による 影響に対しても検討を行う。これらの検討により作成されたデータ ベースから人体の皮虚表面温度と空気温度との差による各部位及び 全身の対流熱伝達率の回帰式及び顕熱放散量に対する対流熱伝達量 と対流熱伝達率の回帰式を提案する。これらのデータベースは、多 分割生理モデルや実人体形状モデルを用いた温熱環境解析の検討用 データや数値流体力学(CFD)解析などの境界条件として用いられる。

\section{2. 人体各部位における対流熱伝達率の算出プロセス}

人体と周辺環境との熱交換は式(1)に示す熱平衡式に従う。すなわ ち、人体と環境との間には温度差による顕熱伝達や水蒸気圧の差に よる水蒸気移動に伴う潜熱伝達が生じる。しかし、本研究では実人 体の代わりに実験サーマルマネキンを使用するため、式(2)に示すよ うに人体の顕熱伝達のみを取り扱う。

人体各部位の対流熱伝達率の算出に関して図 1 に全般的なプロセ スを示す。室内の静穏気流環境を想定した恒温チャンバーで実験を 行い、実験サーマルマネキンの 16 部位ごとに顕熱放散量 $\mathrm{Q}_{\mathrm{b}, \mathrm{i}}$ と皮盧 表面温度 $\mathrm{T}_{\mathrm{s}, \mathrm{i}}$ を測定し、実験室の空気 $\mathrm{T}_{\mathrm{aj}}$ 及び壁面温度 $\mathrm{T}_{\mathrm{w} \mathrm{j}}$ を測定す る。放射解析 ${ }^{12)}$ は、実験から得られたデータ（サーマルマネキンの 皮膚表面温度 $\mathrm{T}_{\mathrm{s}, \mathrm{i}}$ と実験室壁面温度 $\mathrm{T}_{\mathrm{w}, \mathrm{i}}$ ) に基づいて、実験サーマル マネキンとほぼ同形状・同面積の数値サーマルマネキンを用いて式 (4)により各部位表面の分割要素ごとに詳細に行う。本放射解析では 数值サーマルマネキン及び解析空間の各分割要素において入射する 放射熱伝達量（式(5)）と放出及び反射する熱量（式(6)）を求める。 放射解析の結果、実験サーマルマネキンの各部位の対流・放射熱伝 達量が式(7)により明確に分離され、各部位の熱伝達量と皮膚温度、 実験室の平均空気温度により人体各部位の対流熱伝達率が算出され る(式(8))。

$$
\begin{aligned}
& M-W=Q_{s k}+Q_{\text {res }} \\
& =\left(Q_{c}+Q_{r}+E_{s k}\right)+\left(C_{r e s}+E_{r e s}\right) \\
& Q_{t, i}=Q_{c, i}+Q_{r, i} \\
& Q_{c, i}=h_{c, i}\left(T_{s, i}-T_{a}\right) \\
& Q_{r, i}=\left(\sigma \varepsilon_{i} T_{s, i}{ }^{4}-\varepsilon_{i} J_{i}\right) \\
& J_{i}=\sum_{j=1}^{N} F_{i j} G_{j} \\
& G_{i}=\sigma \varepsilon_{i} T_{w, j}{ }^{4}+\left(1-\varepsilon_{i}\right) J_{i}
\end{aligned}
$$

\section{3. 実験概要}

\section{1 実験室及び測定概要}

実験は室内の静稳な気流環境が再現できる東京大学生産技術研究 所の恒温チャンバー $(3.5 \mathrm{~m} \times 3.0 \mathrm{~m} \times 2.5 \mathrm{~m})$ で行った。恒温チャンバ 一の空調方式は床全面吹出し、天井全面吸込みとなっている (図 2)。 空間空気温度と周壁面温度はハンダ接合された $\phi 0.32 \mathrm{~mm} の \mathrm{~T}$ 型 熱電対を用いて測定している。空間空気温度は ISO7726 ${ }^{13)}$ で推奖し ている床面から高さ $0.1 \mathrm{~m} 、 0.6 \mathrm{~m} 、 1.1 \mathrm{~m} 、 1.7 \mathrm{~m}$ の 4 点を測定し、周 壁面温度は壁面を均一に分割して 20 点を測定している。実験サーマ ルマネキンと共に温度測定は 10 秒間隔で 30 分間測定し、その平均 値を 1 回の測定結果としている。実験は 1 つのケースにおいて 3 回 ずつ繰り返し、その平均値を代表値としている。実験期間中、チャ ンバー内の空間平均空気温度は $26 \pm 0.2^{\circ} \mathrm{C} 、$ 上下温度及び平均空気温 度との温度差は常に $0.1^{\circ} \mathrm{C}$ 以下に保たれている。恒温チャンバー内の 風速は超音波風速計を用いて測定し、風速 $0.05 \mathrm{~m} / \mathrm{s}$ 以下、乱れの強 さ $33.3 \%$ 以下の静穏な気流環境となっていることを確認している。 なお、床吹出方式のチャンバーは、人体からの熱上昇流が未発達の 足部位などでは対流伝熱がこの吹出気流の性状に影響される可能性 が生ずる。その意味で本実験による足部の結果の解析に関しては注 意が必要となる。

\section{2 実験サーマルマネキンの概要}

実験では表 2の面積を有する16部位分割の女性形状のサーマルマ

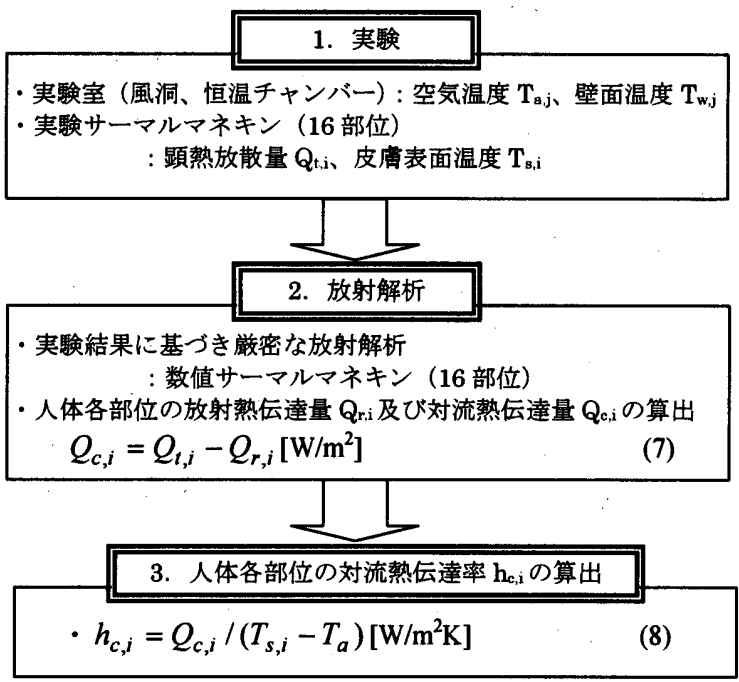

図 1 人体各部位の対流熱伝達率の算出プロセス

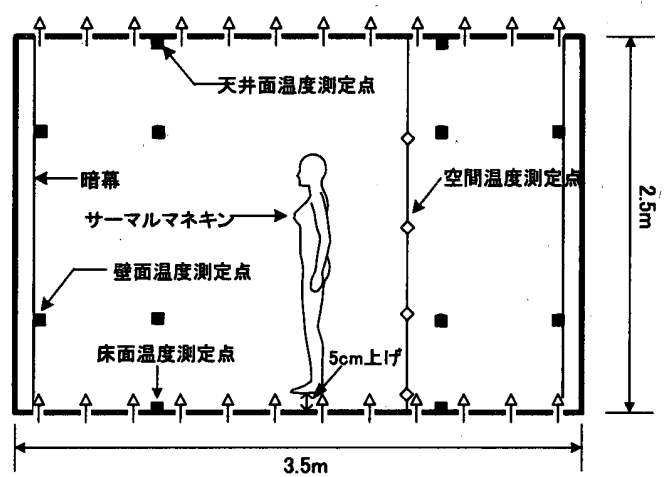

図 2 恒温チャンバーの寒験概要 
表 1 実験及び放射解析ケース

\begin{tabular}{|c|c|c|c|c|c|}
\hline \multirow{3}{*}{\multicolumn{2}{|c|}{ Case }} & \multicolumn{4}{|c|}{ 実験条件 } \\
\hline & & \multicolumn{2}{|c|}{ サーマルマネキン } & \multicolumn{2}{|c|}{$\begin{array}{c}\text { 恒温 } \\
\text { チャン゙ー }\end{array}$} \\
\hline & & 姿勢及び什器 & $\begin{array}{c}\text { 顕熱放散量 } \\
{\left[\mathrm{W} / \mathrm{m}^{2}\right]}\end{array}$ & $\begin{array}{l}\text { 風速 } \\
{[\mathrm{m} / \mathrm{s}]}\end{array}$ & $\begin{array}{l}\text { 温度 } \\
{\left[{ }^{\circ} \mathrm{C}\right]}\end{array}$ \\
\hline \multirow{4}{*}{ Case 1} & $1 \cdot 1$ & \multirow{4}{*}{ 立位 } & 49.1 & \multirow{11}{*}{0.05} & \multirow{11}{*}{$\begin{array}{c}26 \\
\pm 0.1\end{array}$} \\
\hline & 1.2 & & 55.1 & & \\
\hline & $1 \cdot 3$ & & 64.1 & & \\
\hline & 1.4 & & 76.3 & & \\
\hline \multirow{3}{*}{ Case2 } & $2 \cdot 1$ & \multirow{3}{*}{ 坐位 } & 43.1 & & \\
\hline & $2 \cdot 2$ & & 49.1 & & \\
\hline & $2 \cdot 3$ & & 78.5 & & \\
\hline \multirow{4}{*}{ 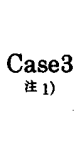 } & $3 \cdot 1$ & デスク & \multirow{4}{*}{49.1} & & \\
\hline & 3.2 & パーティション䄇タ) & & & \\
\hline & $3 \cdot 3$ & パソコン化 & & & \\
\hline & $3 \cdot 4$ & $\begin{array}{c}\text { パーティション+ } \\
\text { 腕上げ(住5) }\end{array}$ & & & \\
\hline
\end{tabular}

注 1) Case3 でのサーマルマネキンの姿勢は座位である。

注 2) デスク：室内に什器がデスクのみの場合

注 3) パーティション: 什器がデスクとパーティションの 2 種類がある場合

注 4) パソコン : 什器がデスク、パーティション、デスクトップパソコンの 3 種類がある場合

注 5) パーティション+腕上げ：Case3-2 と同様な什器の組合として、人体 はテーブルに近く着席し、腕はデスク上に掛けている場合。

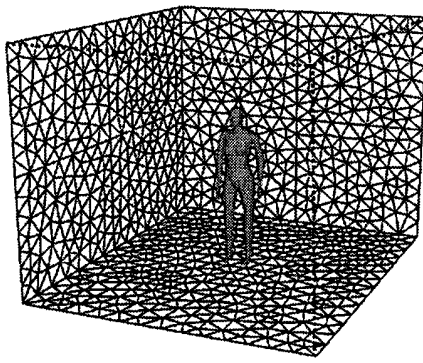

(a) Case I：立位状態

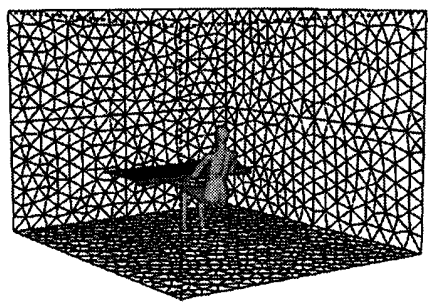

(c) Case3-1 : テーブル

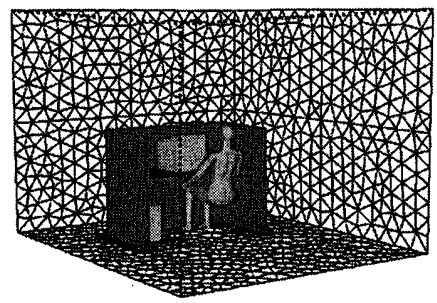

(e) Case3-3 : パソコン (f) Case3-4 : パーティション、腕上げ 図 3 放射解析の対象空間
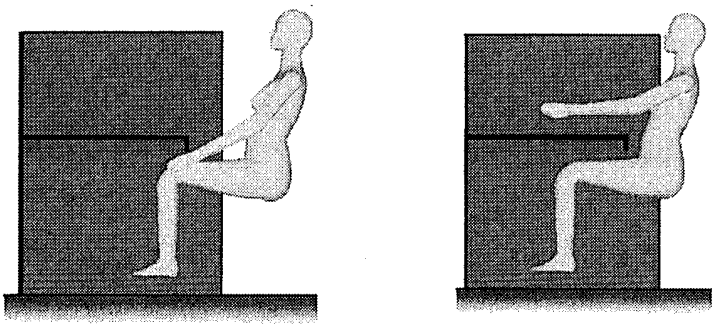

(a) Case3-2 : パーティション (b) Case3-4 : パーティション、腕上げ 図 4 Case3-2 と 3-4 の姿勢変化の詳細 （放射解析メッシュの一部分抬大図）

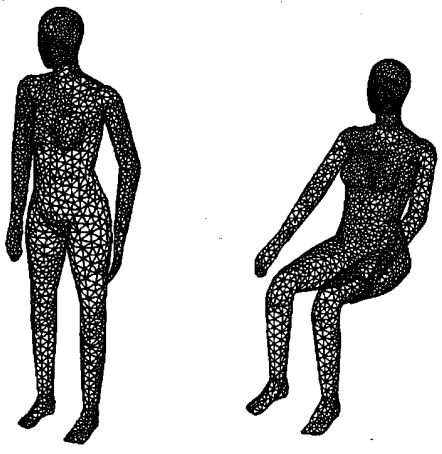

$\begin{array}{ll}\text { (a) 立位状態 } & \text { (b) 座位状態 }\end{array}$

図 5 数值サーマルマネキンの外観

表 2 実験及び立位・座位の数值サーマルマネキンの面積

\begin{tabular}{c|c||c|c|c}
\hline \multirow{2}{*}{ No. } & \multirow{2}{*}{ 部位 } & \multicolumn{3}{|c}{ 面積 $\left[\mathrm{m}^{2}\right]$} \\
\cline { 3 - 5 } & 実験用 & 立位・数值用 & 座位 ・数值用 \\
\hline 1 & 左足 & 0.044 & 0.042 & 0.042 \\
\hline 2 & 右足 & 0.043 & 0.042 & 0.042 \\
\hline 3 & 左下腿 & 0.089 & 0.082 & 0.082 \\
\hline 4 & 右下腿 & 0.089 & 0.082 & 0.082 \\
\hline 5 & 左大腿 & 0.163 & 0.164 & 0.163 \\
\hline 6 & 右大腿 & 0.165 & 0.164 & 0.163 \\
\hline 7 & 腹 & 0.174 & 0.146 & 0.171 \\
\hline 8 & 頭 & 0.100 & 0.117 & 0.117 \\
\hline 9 & 左手 & 0.038 & 0.030 & 0.030 \\
\hline 10 & 右手 & 0.037 & 0.030 & 0.030 \\
\hline 11 & 左前腕 & 0.050 & 0.047 & 0.047 \\
\hline 12 & 右前腕 & 0.050 & 0.047 & 0.047 \\
\hline 13 & 左上腕 & 0.074 & 0.072 & 0.072 \\
\hline 14 & 右上腕 & 0.078 & 0.072 & 0.072 \\
\hline 15 & 胸 & 0.144 & 0.142 & 0.142 \\
\hline 16 & 背中 & 0.133 & 0.121 & 0.121 \\
\hline & 全身 & 0.1471 & 1.400 & 1.423 \\
\hline
\end{tabular}

表 3 有効放射面積の他研究との比較

\begin{tabular}{|c|c|c|c|c|c|}
\hline \multicolumn{2}{|c|}{ 対象モデル } & $\begin{array}{l}\text { 身長 } \\
\text { [m] }\end{array}$ & $\begin{array}{c}\text { 表面積 } \\
{\left[\mathrm{m}^{2}\right]}\end{array}$ & $\begin{array}{c}\text { 有効放 } \\
\text { 射面積 } \\
{\left[\mathrm{m}^{2}\right]}\end{array}$ & $\begin{array}{c}\text { 有効放射 } \\
\text { 面樌率 } \\
{[-]}\end{array}$ \\
\hline \multirow{3}{*}{ 本研究 } & 立位 & \multirow{3}{*}{1.67} & 1.47 & 1.28 & 0.87 \\
\hline & 座位 & & 1.48 & 1.25 & 0.85 \\
\hline & 座位、腕上げ & & 1.49 & 1.28 & 0.86 \\
\hline \multirow{2}{*}{ 大黒 } & 立位 & \multirow{2}{*}{1.60} & \multirow{2}{*}{1.47} & 1.25 & 0.85 \\
\hline & 座位 & & & 1.18 & 0.80 \\
\hline \multirow{2}{*}{ 尾関 } & 立位 & \multirow{2}{*}{1.75} & \multirow{2}{*}{1.72} & 1.28 & 0.74 \\
\hline & 座位 & & & 1.18 & 0.69 \\
\hline \multirow{2}{*}{ Fanger } & 立位 & \multirow{2}{*}{1.72} & \multirow{2}{*}{1.74} & 1.27 & 0.73 \\
\hline & 座位 & & & 1.22 & 0.70 \\
\hline
\end{tabular}

ネキンを用いる ${ }^{14)}$ 。実験において想定した顕熱放散量をサーマル マネキンの投入熱量として与える。サーマルマネキンの姿勢は立 位、座位を想定し、裸体状態にして恒温チャンバーの中央に床面 から $5 \mathrm{~cm}$ 上げて設置する（図 2)。これは、サーマルマネキンと床 面との熱伝導を避けるためである。

\section{3 実験及び放射解析ケース（表 1、图 3、图 4)}

実験及び放射解析ケースの詳細は表 1、図 3 に示す。Case1 と Case2 は室内の静稳な気流環境においてそれぞれ立位と座位状態 で人体の顕熱放散量や姿勢の違いによる対流熱伝達率の変化を調 べることを目的としている。Case3 : は一般オフィスを想定し、人 体に近接する什器や人体の姿勢変化が人体の対流熱伝達率に及ぼ す影響を検討する。人体に近接する什器は座位姿勢の人体に対し 
デスクを基準としてパーティションとデスクトップパソコンをケー スの順番に加える。Case3-4 は Case3-2 と同一の什器の組合せにおい て実験サーマルマネキンの腕をデスク上に置き、体をよりデスクに 近く着席させること（図 4 参考）で、同一顕熱放散量と什器の組合 せにおいて姿勢変化が部位別の対流熱伝達率に及ぼす影響を検討す る。座位時の実験は着衣量がほぼ Oclo 值の椅子を用いる。

\section{4. 放射解析}

\section{1 数值サーマルマネキンの概要}

実験サーマルマネキンの寸法と表面積がほぼ対応する数值サーマ ルマネキンを用いて放射解析を行う。その各部位の面積を表 2 に、 外観を図 3 に示す。立位と座位の数值サーマルマネキンは実験サー マルマネキンの全身面積に対してそれぞれ約 $95 \%$ と $97 \%$ となってい る。また、本研究で用いた立位、座位、座位で腕を上げた姿勢の数 值サーマルマネキンと他研究で用いられた人体モデルの表面積及び 有効放射面積などを表 3 で比較する。本研究の数值サーマルマネキ ンにおいて各姿勢の表面積が多少異なるのはメッシュの作成時の誤 差である。表面積に関しては本研究の数值サーマルマネキンと大黒 $ら^{8), 9)}$ のものはほほ同様であり、尾関ら ${ }^{17)}$ と Fanger ${ }^{18)}$ と比較すると 約 $0.26 \mathrm{~m}^{2}$ 程度小さい。有効放射面積や有効放射面積率では、本研究 の立位のものと大黒らのものはほぼ同様であるが、座位状態におい ては着席姿勢、寸なわち両手や両脚の相互位置関係などにより差異 が生じている。数值サーマルマネキンの表面メッシュ数は、立位が 5,702 個、座位が 5,892 個、座位の腕上げが 6,696 個である。

\section{2 解析対象空間}

図 3 に放射解析対象空間を示す。実験が行われた恒温チャンバー の寸法と形状を考虑した空間に立位及び座位の数值サーマルマネキ ンを取り込んで放射解析の対象空間を作成する。空間の壁面は 3,506 個の要素に分割されている。Case3 の場合は実験で使われた什器の 寸法と面積を考虑し、座位の数値サーマルマネキンのメッシュに加 えて解析対象空間を作成する。座位の場合、実験でほぼ 0clo 值の椅 子を使用したため、放射解析では椅子の効果を無視し、メッシュの 作成を省略する。

\section{3 解析概要}

実験から得られた実験サーマルマネキン皮唐表面温度 $\mathrm{T}_{\mathrm{s}, \mathrm{i} \text { 、 }}$ 実験室 の周壁面温度 $\mathrm{T}_{\mathrm{w} \mathrm{j}}$ を境界条件として、尾関ら ${ }^{12}$ の提案による形態俰 数算出の数值積分法に基づいた放射解析を行う。相反則に基づく形 態係数の誤差が $2 \%$ 以上の要素に対して形態係数の総和が 1.0 になる ように修正を行う。本研究では数値サーマルマネキンの放射率は 0.95、周壁面の放射率は $0.94^{19)}$ とする。

\section{5. 立位状態における放射解析の結果}

\section{1 放射熱伝達量（図 6 (a))}

顕熱放散量の増加 $\left(49.1 \sim 76.3 \mathrm{~W} / \mathrm{m}^{2}\right)$ に伴い各部位における相互 間の放射熱伝達量の差異が大きくなっているが、增加の傾向には差 異がない。Case1 の全ケースにおいて、腹、胸、背中の胴部は全身 の平均值より約 $5 \sim 9 \mathrm{~W} / \mathrm{m}^{2}$ (約 2 割) 程度大きく、両手と両足は約 6 $\sim 9 \mathrm{~W} / \mathrm{m}^{2}$ (約 2 割) 程度低い。各ケースにおいて全身の放射熱伝達
量は 33.7、37.0、43.4、50.6W/ $/ \mathrm{m}^{2}$ である。

\section{2 放射熱伝達率}

ASHRAE $^{20)}$ が提案する全身の放射熱伝達率の算出式を式(9)に示 す。式(9)に立位の数値サーマルマネキンの有効放射面積率 $\left(A_{r} / A_{D}\right)$ 0.872 と実験サーマルマネキンの全身の平均皮膚温度、平均周壁面温 度を用いて Case1-1〜1-4 の放射熱伝達率を算出すると、それぞれ $5.2 、$ 5.2、5.2、5.3 W/m $/ \mathrm{m}^{2} \mathrm{~K}$ となり、平均は約 $5.2 \mathrm{~W} / \mathrm{m}^{2} \mathrm{~K}$ となる。これは水 平円筒を用いた Rapp ${ }^{21)} の$ 放射熱伝達率 $5.2 \mathrm{~W} / \mathrm{m}^{2} \mathrm{~K}$ と同様である。し かし、Fanger ${ }^{18)}$ が提案した立位状態の有効放射面積率 0.73 を用いる 場合、全身の放射熱伝達率は約 $4.4 \mathrm{~W} / \mathrm{m}^{2} \mathrm{~K}$ となり、本研究の結果よ り約 $0.8 \mathrm{~W} / \mathrm{m}^{2} \mathrm{~K}$ 程度低い。しかし、Nishiら ${ }^{22)}$ の結果である $5.2 \mathrm{~W} / \mathrm{m}^{2} \mathrm{~K}$ とはほぼ一致している。

$$
h_{r}=4 \varepsilon \sigma \frac{A_{r}}{A_{D}}\left(273.2+\frac{T_{c l}-\bar{T}_{r}}{2}\right)^{3}
$$

\section{3 対流熱伝達量（图 6 (b))}

Case1の各ケースにおける全身の対流熱伝達量は 15.4、18.1、20.8、 $25.7 \mathrm{~W} / \mathrm{m}^{2}$ となっており、放射熱伝達量の約 5 割程度である。この結 果により、環境の放射温度（MRT）と空気温度がほほ等しく、静稳 気流環境における人体の放熱性状は対流熱伝達より放射熱伝達が支 配的である従来の指摘が妥当であることが確認される。全ケースに おいて頭、両手、両前腕、両足が全身の平均值より約 $3 \sim 7 \mathrm{~W} / \mathrm{m}^{2}$ (約 $2 、 3$ 割) 程度大きく、腹、胸、背中は約 $5 \sim 8 \mathrm{~W} / \mathrm{m}^{2}$ (約 $2 、 3$ 割) 程度低い。なお、本研究で使用している恒温チャンバーは床全面吹 出空調方式のため、直接風が当たる両足は対流熱伝達量が大きくな っており、本研究結果を利用する際には注意が必要である。

各部位及び全身の対流熱伝達量の顕熱放散量に対する回帰式を表 4 の左側に示す。脚や腕などの左右がある部位においては平均値を 用いて表す。

\section{4 対流熱伝達率（図 6（c）、表 4）}

各ケースにおいて全身の対流熱伝達率は 2.4、2.6、2.5、2.7W/ $/ \mathrm{m}^{2} \mathrm{~K}$ である。静穏な気流環境における顕熱放散量の変化が立位状態の人 体各部位の対流熱伝達率に及ぼす影響は非常に小さいが、部位毎の 対流熱伝達率の変化は確認することができる。頭と両手、両足の末 端部は全身の平均値より約 $1.1 \sim 1.3 \mathrm{~W} / \mathrm{m}^{2} \mathrm{~K}$ (約 5 割) 程度大きく、 腹、胸、背中の胴体は約 $1 \mathrm{~W} / \mathrm{m}^{2} \mathrm{~K}$ (約 4 割) 程度低い。

室内温度がある程度一定に保たれている一般的な居室及びオフィ ス内において人体が高代勆量の活動を行う可能性は極めて低いが、 顕熱放散量が著しく変化した場合でも、本解析結果より静稳気流環 境では対流熱伝達率の変化は非常に小さく、人体の顕熱放散量によ る対流熱伝達率の全身及び部位別の変化は無視できると考えられる。 表 4 に顕熱放散量の変化に伴う実験サーマルマネキンの平均皮膚 温度と平均空間空気温度 $\left(26.1^{\circ} \mathrm{C}\right)$ との差による各部位及び全身の 対流熱伝達率の回帰式を示す。脚や腕などの左右がある部位におい ては平均值を用いて表す。

\section{6. 座位状龍における放射解析の結果}




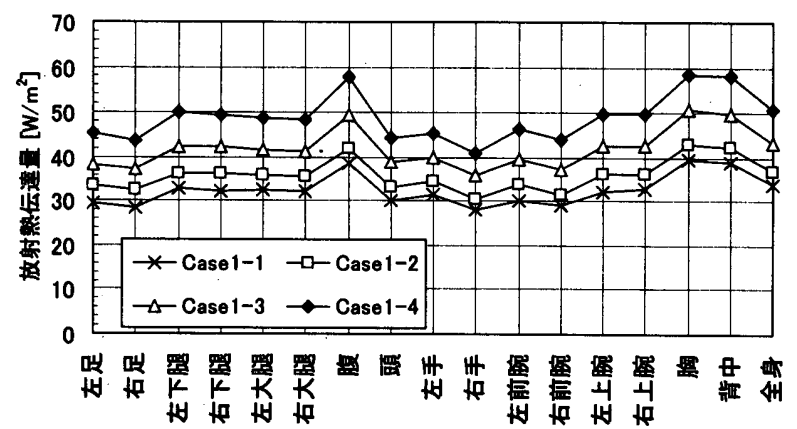

（a）放射熱伝達量 [W/m²]

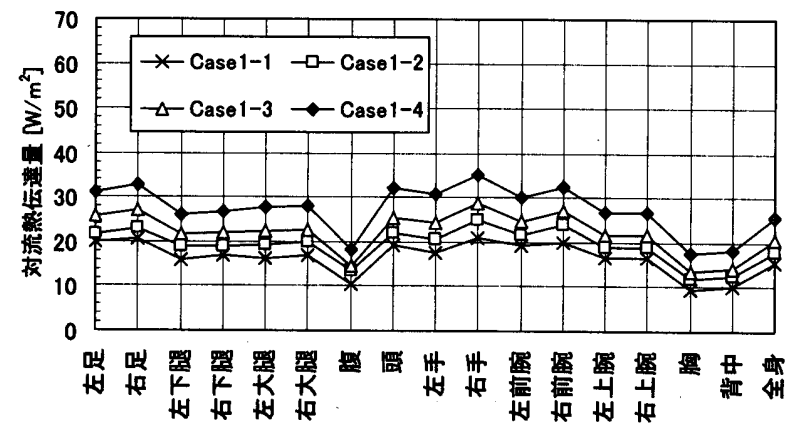

（b）対流熱伝達量 $\left[\mathrm{W} / \mathrm{m}^{2}\right]$

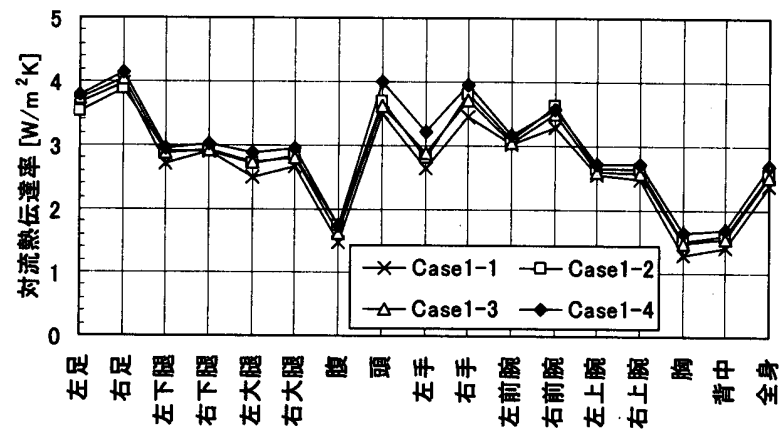

(c) 対流熱伝達率 $\left[\mathrm{W} / \mathrm{m}^{2} \mathrm{~K}\right]$

図 6 立位状態の人体における各部位の

放射・対流熱伝達量及び対流熱伝達率

表 4 立位時における人体各部位の対流熱伝達率の回㷌式

\begin{tabular}{c|c}
\hline 部位 & 対流熱伝達率 $\left(\mathrm{h}_{\mathrm{c}}\right)\left[\mathrm{W} / \mathrm{m}^{2} \mathrm{~K}\right]$ \\
\hline 足 & $3.09 \cdot \Delta \mathrm{T}^{0.12}{ }^{\text {i } 1)}$ \\
\hline 下腿 & $1.28 \Delta \mathrm{T}^{0.12}$ \\
\hline 大腿 & $1.66 \Delta \mathrm{T}^{0.25}$ \\
\hline 腹 & $0.95 \Delta \mathrm{T}^{0.26}$ \\
\hline 頭 & $2.07 \Delta \mathrm{T}^{0.31}$ \\
\hline 手 & $1.57 \Delta \mathrm{T}^{0.37}$ \\
\hline 前腕 & $2.66 \Delta \mathrm{T}^{0.1}$ \\
\hline 上腕 & $1.97 \Delta \mathrm{T}^{0.14}$ \\
\hline 胸 & $0.47 \Delta \mathrm{T}^{0.52}$ \\
\hline 背中 & $0.67 \Delta \mathrm{T}^{0.39}$ \\
\hline 全身 & $1.51 \Delta \mathrm{T}^{0.25}$ \\
\hline
\end{tabular}

注 1）温度差 $\Delta \mathrm{T}$ は実験サーマルマネキンの皮唐表面温度と恒温チャン バーの平均空気温度との差

\section{1 放射熟伝達量（图 7 (a))}

Case2 の各ケースの全身の顕熱放散量 $\left(43.1 、 49.1 、 78.5 \mathrm{~W} / \mathrm{m}^{2}\right)$ に 対し、放射熱伝達量は 28.3、32.0、49.6W/ $\mathrm{m}^{2}$ である。全ケースにお いて、腹、胸、背中の胴部は全身の平均値より約 $2.1 \sim 11 \mathrm{~W} / \mathrm{m}^{2}$ 程度

(約 $1 、 2$ 割) 大きく、両足と両大腿、両手、両前腕、両上腕は約 $5.8 \sim 9.1 \mathrm{~W} / \mathrm{m}^{2}$ 程度（約 2 割）低い。

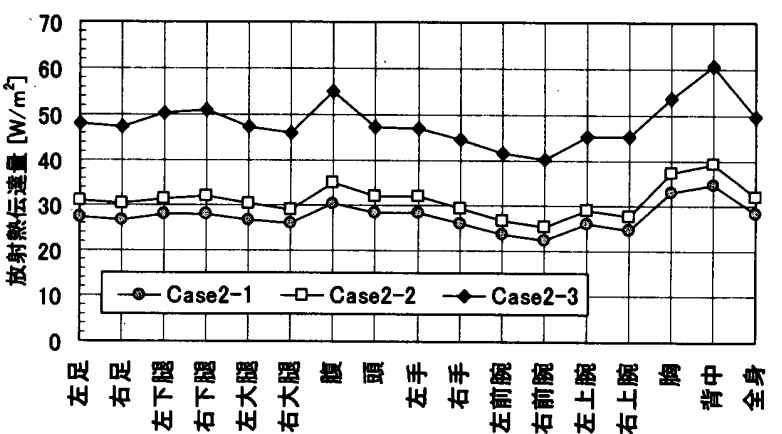

(a) 放射熱伝達量 $\left[\mathrm{W} / \mathrm{m}^{2}\right]$

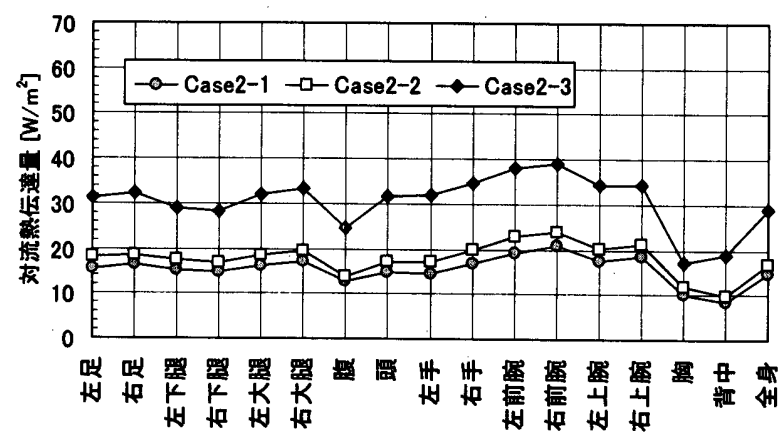

（b）対流熱伝達量 $\left[\mathrm{W} / \mathrm{m}^{2}\right]$

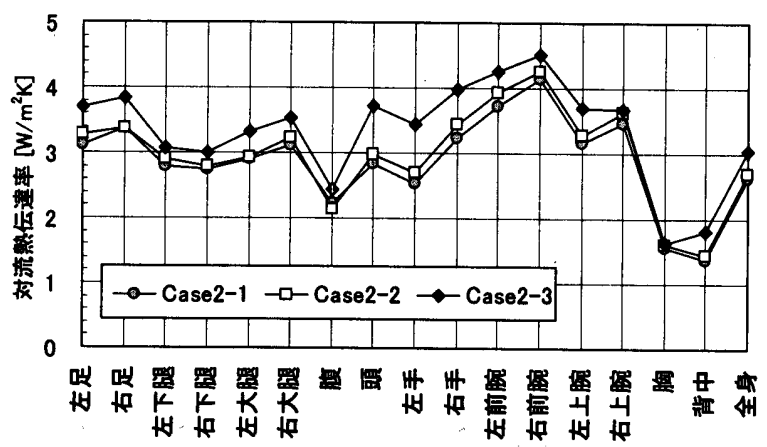

(c) 対流熱伝達率 $\left[\mathrm{W} / \mathrm{m}^{2} \mathrm{~K}\right]$

図 7 座位状態の人体における各部位の 放射・対流熱伝達量及び対流熱伝達率

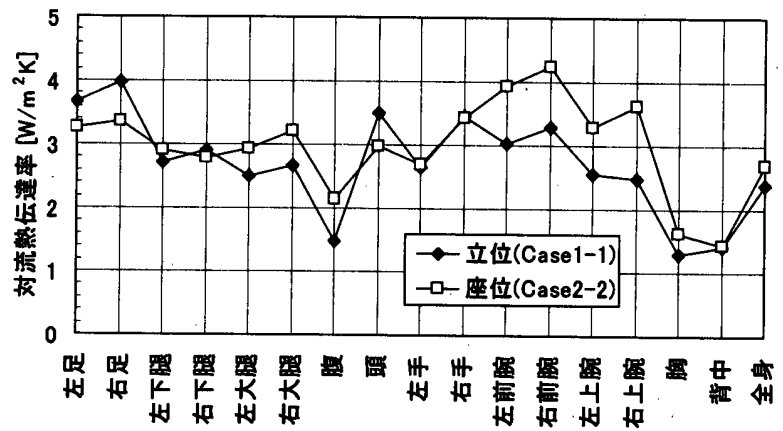

図 8 同一顥熱放散量における立位と座位状態 における各部位の対流熱伝達率の比較

\section{2 放射熱伝達率}

座位の数值サーマルマネキンにおける有効放射面積率 0.844 を用 いて式(9)により Case2-1〜2-3 の放射熱伝達率を算出すると、それぞ れ 5.0、5.0、5.1 W/m² $\mathrm{K}$ となり、平均值は約 $5.0 \mathrm{~W} / \mathrm{m}^{2} \mathrm{~K}$ となる。Fanger ${ }^{18)}$ が提案した座位状態の有効放射面積率 0.7 を用いると、全身の放射 熱伝達率は約 $4.2 \mathrm{~W} / \mathrm{m}^{2} \mathrm{~K}$ となり、本研究の平均値より約 $0.8 \mathrm{~W} / \mathrm{m}^{2} \mathrm{~K}$ 程度低い。本研究の数值サーマルマネキンの有効放射面積率は Fanger ${ }^{18)}$ が提案している值より大きいため、立位状態と同様に座位 
表 5 座位時における人体各部位の対流熱伝達率の回帰式

\begin{tabular}{|c|c|}
\hline 部位 & 対流熱伝達率 $\left(\mathrm{h}_{\mathrm{c}}\right)\left[\mathrm{W} / \mathrm{m}^{2} \mathrm{~K}\right]$ \\
\hline 足 & $1.82 \Delta T^{0.32}$ (住) \\
\hline 下腿 & $2.1 \Delta \mathrm{T}^{0.16}$ \\
\hline 大腿 & $2.02 \Delta \mathrm{T}^{0.24}$ \\
\hline 腹 & $1.5 \Delta \mathrm{T}^{0.22}$ \\
\hline 頭 & $2.07 \Delta \mathrm{T}^{0.31}$ \\
\hline 手 & $1.18 \Delta \mathrm{T}^{0.52}$ \\
\hline 前腕 & $2.9 \Delta \mathrm{T}^{0.18}$ \\
\hline 上腕 & $2.46 \Delta \mathrm{T}^{0.19}$ \\
\hline 胸 & $1.44 \Delta \mathrm{T}^{0.055}$ \\
\hline 背中 & $0.57 \Delta \mathrm{T}^{0.54}$ \\
\hline 全身 & $1.61 \Delta$ \\
\hline
\end{tabular}

注 1）温度差 $\Delta \mathrm{T}$ は実験サーマルマネキンの皮虞表面温度と恒温チャンバー の平均空気温度との差

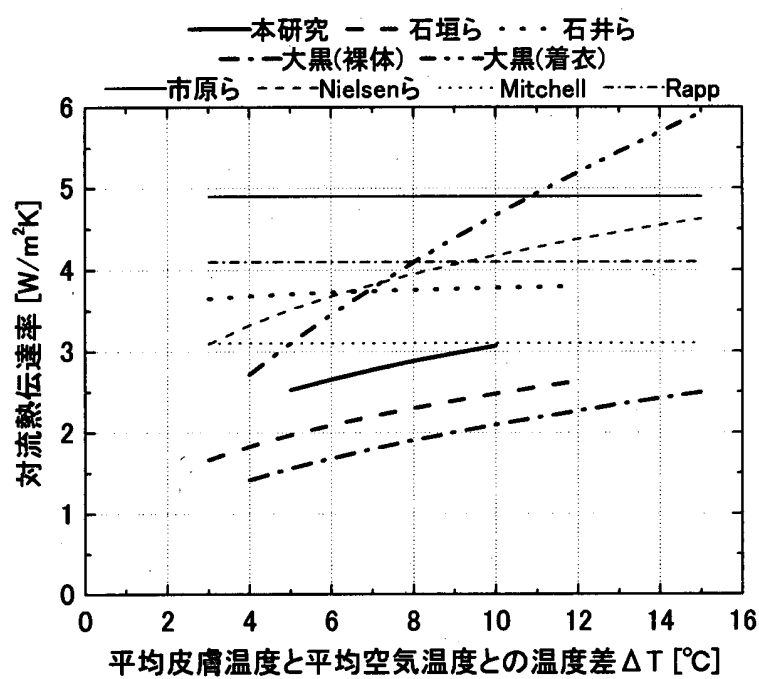

図 9 座位時における人体の全身対流熱伝達率の 他研究との比較

状態においても既存に通常使われている人体の放射熱伝達率より大 きい。

6.3 対流熱伝達量（图 7 (b))

Case2 の各ケースの全身の対流熱伝達量は $14.8 、 17.0 、 28.9 \mathrm{~W} / \mathrm{m}^{2}$ である。これは放射熱伝達量の約 $5 、 6$ 割程度であり、立位状態と同 様に座位状態においても静稳な気流環境においては対流熱伝達より 放射熱伝達が支配的であることが明らかである。全ケースにおいて 腹、胸、背中は全身の平均値より約 $2 \sim 11.8 \mathrm{~W} / \mathrm{m}^{2}$ 程度（約 $1 \sim 4$ 割）

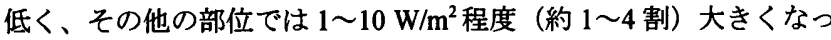
ている。

各部位及び全身の対流熱伝達量を顕熱放射量に対する回帰式とし て表 5 に示す。脚や腕などの左右がある部位においては平均值を用 いて表す。

\section{4 対流熱伝達率（図 7 (c)、表 5)}

立位状態での結果と同様に、座位状態においても静榣な気流環境 では顕熱放散量の変化が人体の各部位及び全身の対流熱伝達率に及 ぼす影響は少ないが、部位毎による変化は確認することができる。 各ケースにおいて全身の対流熱伝達率は 2.6、2.7、3.1W/ $\mathrm{m}^{2} \mathrm{~K}$ である。 Case2-1 と Case2-2 では顕熱放散量の変化が $6 \mathrm{~W} / \mathrm{m}^{2}$ 程度で対流熱伝 達率の変化が少ないが、Case2-3 では $35.5 \mathrm{~W} / \mathrm{m}^{2}$ の差があり(表 1)、脚 や腕、頭部等の身体末端部では対流熱伝達率が全身の平均值より最 大 $1.5 \mathrm{~W} / \mathrm{m}^{2} \mathrm{~K}$ （約 $5 、 6$ 割）程度大きく、腹、胸、背中の胴体は最大
$1.2 \mathrm{~W} / \mathrm{m}^{2} \mathrm{~K}$ （約 $4 、 5$ 割）程度低い。

一般的な居室環境において座位状態で高代謝量の活動を行う可能 性は低い。従って、代謝量の変化に伴う顕熱放散量の変化による各 部位及び全身の対流熱伝達率の変化は無視できると考えられる。

顕熱放散量の変化に伴う実験サーマルマネキンの皮膚表面温度と 平均空間空気温度 $\left(26.1^{\circ} \mathrm{C}\right)$ との差による各部位及び全身の対流熱 伝達率の回帰式を表 5 に示す。

\section{5 同一顕熱放散量における立位と座位の対流熱伝達率の比較(図} 8)

立位と座位で同一顕熱放散量 $\left(49.1 \mathrm{~W} / \mathrm{m}^{2}\right)$ の Case1-1 と Case2-2 において各部位の対流熱伝達率の変化を検討する (図 9 参照)。空調 方式が床全面吹出方式の恒温チャンバーで、ほぼ 0clo 值の椅子を使 用したため、立位状態に比べて座位状態で風に正対する面積が広く なる。この結果、座位状態の全身の対流熱伝達率は立位状態と比べ て大きくなる。また、立位から座位に姿勢を変化させる際、室内の 気流方向に対して向きが変わる大腿と前腕、上腕において立位より 座位の対流熱伝達率が大くなる。これは恒温チャンバーのような非 常に小さい気流速度 $(0.05 \mathrm{~m} / \mathrm{s})$ でも人体の姿勢変化により部位別に 対流熱伝達率が変化することを意味する。

\section{6. 他研究との比較（図 9)}

室内環境における人体の対流熱伝達率の研究は座位状態に対する 研究が多く報告されている。図 9 に、本研究と他研究の全身の対流 熱伝達率の比較を示す。本研究の全身の対流熱伝達率は平均皮䖒温 度と平均空気温度との温度差 5 $10^{\circ} \mathrm{C}$ で約 $2.5 \sim 3.1 \mathrm{~W} / \mathrm{m}^{2} \mathrm{~K}$ に分布し、 大黒ら ${ }^{9}$ が提案した裸体状態のサーマルマネキンの結果と着衣状態 の結果の中間の値となっており、石垣ら ${ }^{23)}$ の結果より若干大きい結 果となっている。しかし、市原ら ${ }^{14)} 、$ Nielsen $5^{24)} 、 M^{24}$ itchell1 ${ }^{25)}$ 、 $\mathrm{Rapp}^{21)}$ の結果とは大きい差が生じている。この差は静稳な気流環境 の場合、対流放射熱伝達量に比べて放射熱伝達量が大きいため、放 射熱伝達量の算出方式の差異により対流熱伝達量の評価に大きな差 異が生じ、対流熱伝達率の算出にも大きな影響を及ぼした結果だと 考えられる。また、対流熱伝達率の算出対象である人体もしくは人 体モデルの形状及び姿勢、有効放射面積率の差異などにより放射熱 伝達量が異なり、最終的には対流熱伝達率にも影響を及ぼしている と考えられる。

\section{7. 什器の熱放散性状に及ぼす影響（座位状態）}

\section{1 放射熱伝達量（図 10 (a)、(b))}

同一の顕熱放散量において什器や姿勢変化の影響を図 10 に示す。 図 10(a)には同一姿勢において Case3-1 から Case3-3 の人体周辺の什 器を増加させたことによる放射熱伝達量の変化を表す。Case3-1〜 3-3 において、放射熱伝達量の全身平均値は 33.5、32.6、31.6W/ $/ \mathrm{m}^{2}$ と周辺什器の増加に伴い減少傾向となる。周辺に什器のない Case2-2 の全身の放射熱伝達量 $32.0 \mathrm{~W} / \mathrm{m}^{2}$ と比べても大きな差はない。頭と胸 は他部位に比べて什器の影響が相対的に少ないため、放射熱伝達量 はほとんど変化しないが、その他の部位では変化が見られる。

図 10 (b)には、同一顕熱放散量と同一什器の組み合わせにおいて 姿勢の変化による放射熱伝達量の変化を示す。腕を上げている 


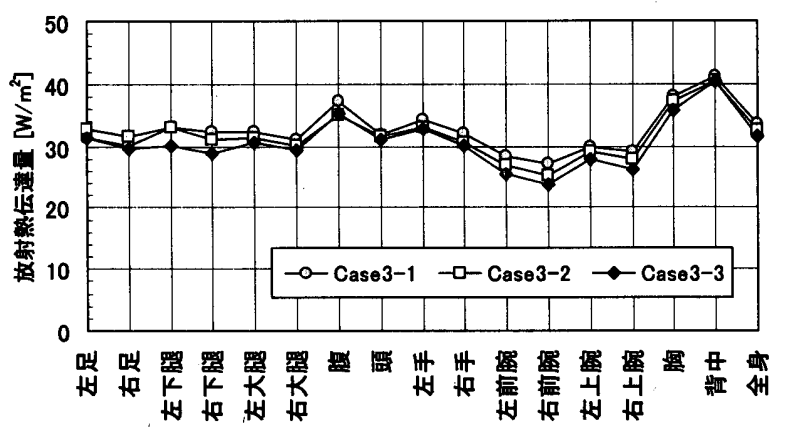

(a) 放射熱伝達量

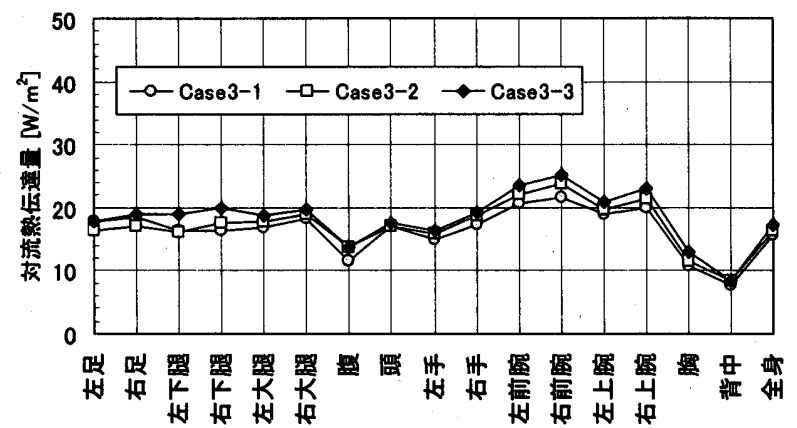

(c) 対流熱伝達量

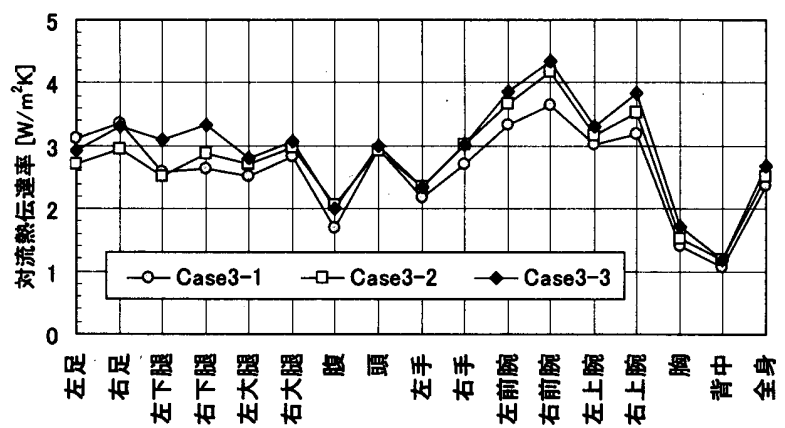

(e) 対流熱伝達率

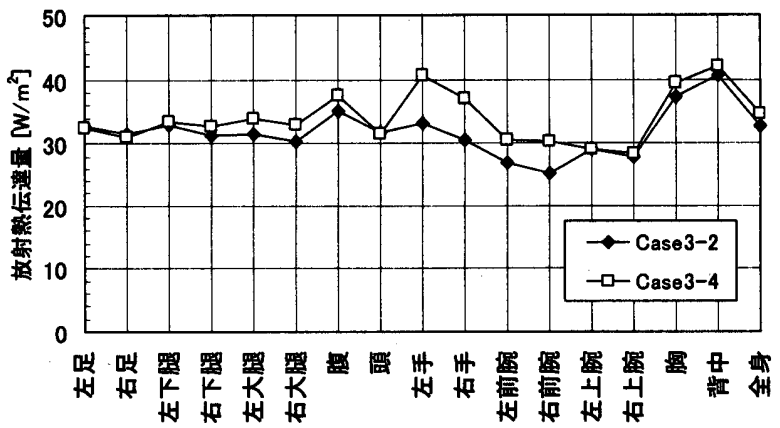

(b) 姿勢変化による放射熱伝達量の変化

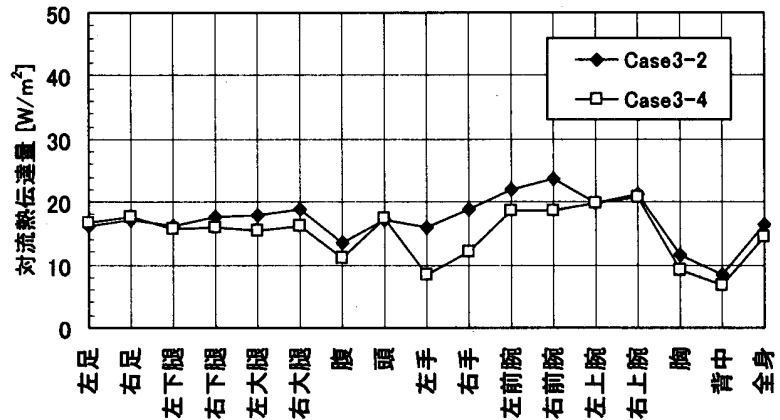

(d) 姿勢変化による対流熱伝達量の変化

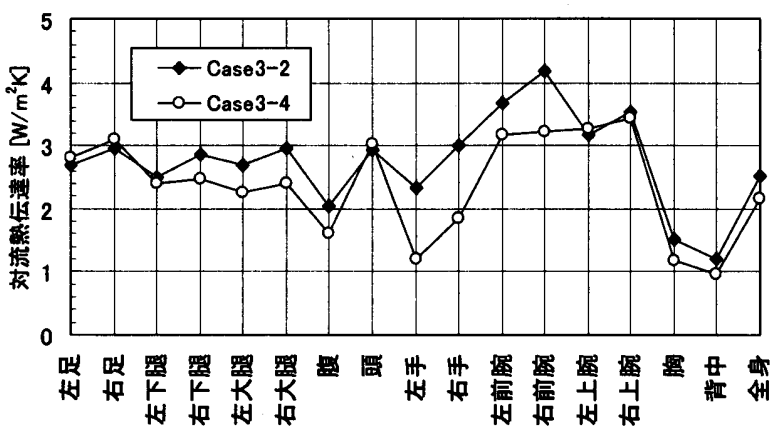

（f）姿勢変化による対流熱伝達率の変化

図 10 座位状態における家具の影響

Case3-4 では、大腿、腹、手、前腕で放射熱伝達量が増加し、全身 では約 $2 \mathrm{~W} / \mathrm{m}^{2}$ 増加する。これはサーマルマネキンがテーブルに接近 して腕をテーブル上に上げたことにより有効放射面積が増えたため である。

\section{2 対流熱伝達量（図 10 (c)、(d))}

什器の増加により放射熱伝達量が若干減少しているため、対流熱 伝達量は全身及び各部位で増加する傾向となる（図 10 (c)参照)。全 身の対流熱伝達量は Case3-1〜3-3 で、それぞれ 15.5、16.3、17.4W/ $/ \mathrm{m}^{2}$ となる。頭と背中では殆ど変化がなく、他部位では最大 $3 \mathrm{~W} / \mathrm{m}^{2}$ 増加 する。

図 10 (d)に、姿勢の変化による対流熱伝達量の変化を示す。大腿、 腹、手、前腕で対流熱伝達量は最大 $7.3 \mathrm{~W} / \mathrm{m}^{2}$ 减少している。全身で は約 $2 \mathrm{~W} / \mathrm{m}^{2}$ 程度の減少が見られる。

\section{3 対流熱伝達率（图 10 (e)、(f))}

図 10 (e)に、人体周辺に什器が増加することによる部位毎の対流 熱伝達率の変化を示す。什器が増加しても皮廉表面温度の変化は約 $\pm 0.2^{\circ} \mathrm{C}$ 以下と小さく、゙゙スクび゙パーティションの表面温度はサー マルマネキンの影響で平均空気温度と壁面温度に対して $0.1 \sim 0.9^{\circ} \mathrm{C}$
高い。また、パソコン及びモニタは自身の発熱により表面温度は平 均空気温度と壁面温度より $2 \sim 14^{\circ} \mathrm{C}$ 高くなっている。従って、サー マルマネキンから放出される放射熱伝達量は低下し、対流熱伝達量 は増加して対流熱伝達率が増加する結果となる。また、全身では約 $0.3 \mathrm{~W} / \mathrm{m}^{2} \mathrm{~K}$ 程度增加する。姿勢変化による変化（図 $10(\mathrm{f})$ 参照）は手 で最大 $1.2 \mathrm{~W} / \mathrm{m}^{2} \mathrm{~K}$ 低くなっており、全身で約 $0.4 \mathrm{~W} / \mathrm{m}^{2} \mathrm{~K}$ 程度減少し ている。什器の配置や姿勢の変化による全身の対流熱伝達率の変化 は微小である。しかし、最大で $1 \mathrm{~W} / \mathrm{m}^{2} \mathrm{~K}$ の変化が見られる部位もあ ることを考慮すると、静稳な気流環境においては顕熱放散量の変化 よりも什器の配置や姿勢変化の影響が局所の対流熱伝達率を検討す る上で重要なポイントになると考えられる。

8. まとめ

(1) 実験サーマルマネキンに対応する立位と座位の数值サーマル マネキンを作成した。室内の静穞気流環境を想定した実験を 床全面吹出天井全面吸込方式の恒温チャンバーで行い、実験 結果を用いた詳細な放射解析により、室内環境における裸体 サーマルマネキンの立位・座位状態での各部位及び全身の対 流熱伝達率を算出した。 
（2）人体の皮膚表面温度と空気温度との差による各部位及び全身 の対流熱伝達率の回帰式を提案した。この回帰式は実人体形 状の人体モデルや多分割生理モデルを用いた CFD 及び数値解 析などに境界条件として用いられる。

（3）立位・座位状態のいずれにおいても、静稳気流環境下の同一 姿勢条件では顕熱放散量の増加に係わらず、対流熱伝達量は 放射熱伝達量の約 5 割となっている。

（4）対流熱伝達率は、立位状態において頭、手、足の身体末端部 が全身の平均值より約 5 割程度高く、腹、胸、背中の胴体が 約 4 割程度低い。座位状態においては末端部が全身の平均値 より約 5、6 割程度高く、胴体が䄪 4、5 割程度低い。但し、 足部等人体周辺に生じる人体発熱による上昇流の影響が及ば ない領域に関しては本研究で用いたチャンバー内気流の性状 の影響がある。

（5）什器の配置や姿勢の変化による全身の対流熱伝達率の変化は 微小であるが、部位的には最大で $1 \mathrm{~W} / \mathrm{m}^{2} \mathrm{~K}$ の変化が見られる。

(6) 室内の静穏な気流環境において、人体の部位別の対流熱伝達 率は人体の姿勢及び什器の影響が大きい。また、対流熱伝達 率は算出対象となる人体もしくは人体モデルの形状、姿勢、 有効放射面積率、放射解析手法などにより大きい差異が発生 する。

（7）本研究は裸体時の人体に対する各部位の対流熱伝達率を算出 している。しかし、通常の人体は着衣状態であるため、本研 究での手法を用いて着衣時の対流熱伝達率を求める必要があ る。また、実人体は皮膚温度調節のため発汗があり、発汗時 に対する対流熱伝達率も求める必要がある。これは今後の課 題とする。

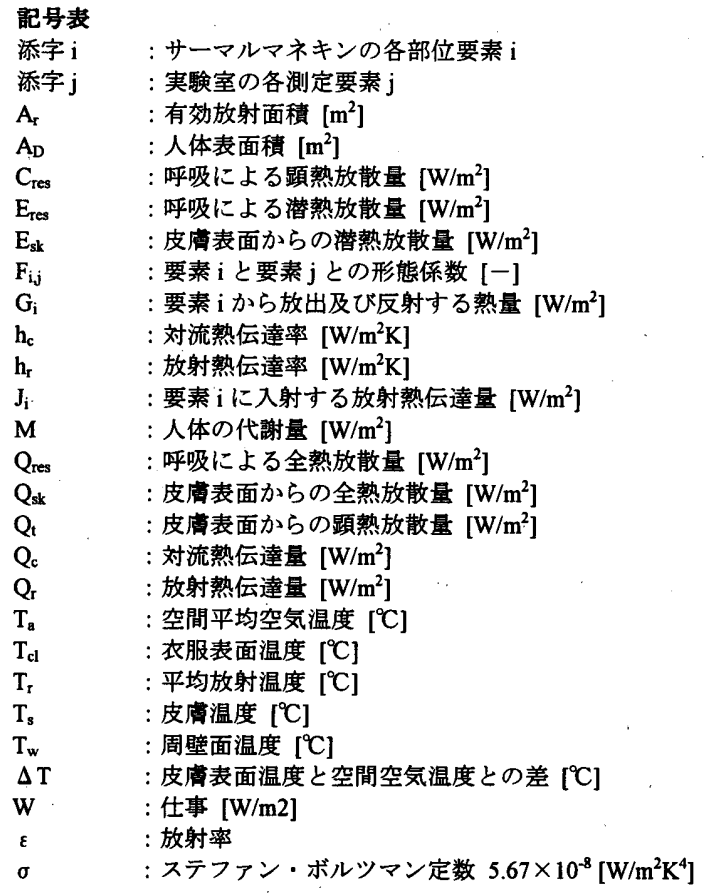

散辞

1) 本解析で用いた放射解析プログラムは旭ガラスの斍藤恒洋氏及び尾関 義一氏の開発による。両氏の御協力に記して謝意を表す。

2) 本研究の一部分は文部科学省の科研費の助成により実施している。関 係各位に謝意を表す。

\section{参考文献}

1) 田辺新一ほか 2 名 : 温熱環境評価のための 65 分割体温調節モデルに関 する研究、日本建築学会計画系論文集 No.541、pp9、2001.3

2) 佐古井智紀ほか 4 名：非定常、不均一環境場における人体熱モデルに 関する研究（その 3) SMITH モデルによる人体の温度分布予測とその 特性分析、日本建築学会大会学術講演会梗概集、pp491-492、2003.9

3）大森敏明ほか 3 名：大規模・複雑形状に対岕寸る対流・放射連成シミ ユレーション用放射伝熱解析法の開発（第 1 報 モンテカルロ法をべ 一スとした高精度放射伝熱解析法)、空気調和・衛生工学会論文集 No.88、ppl03-113、2003.1

4) 加藤信介ほか 2 名: タスク域ワイドカバー型パーソナル空調方式の研 究（その 1) 机上設置上向き吹出型パーソナル空調による人体周辺微気 象の CFD 解析、日本建築学会大会学術諈演会梗概集、pp737-738、2003.9

5）李徹球ほか 2 名: 室内気流の流速と乱れの強さのサーマルマネキン各 部の対流熱伝達率への影響に関する研究、日本建築学会計画系論文集 No.429、pp25-31、1991.11

6）：石井仁ほか 4 名：自然対流時における人体および部位の対流熱伝達率 の推定、日本建築学会計画系論文集 No.530、pp31-37、2000.4

7) 尾関義一ほか 3 名：日射環境下におけるサーマルマネキン周りの対流 熱伝達率の評価、日本建築学会計画系論文集 No.555、pp29-36、2002.5

8) 大黒雅之ほか 4 名 : Convective Heat Transfer Coefficients and Clothing Insulations for Parts of the Clothed Human Body Under Airflow Conditions, 日本建築学会計画系論文集 No.561、pp21-29、2002.11

9) 大黒雅之ほか 4 名 : Convective Heat Transfer Coefficients and Clothing Insulations for Parts of the Clothed Human Body Under Calm Conditions、日 本建築学会計画系論文集 . No.561、pp31-39、2002.11

10) M.C.G. Silva, J.A. Coelho : Convective Coefficients for the Human Body Parts Determined with a Thermal Mannequin, ROOMVENT2002, pp277-280, 2002.9

11）石井仁ほか 3 名: 強制対流における人体の総合熱伝達率及び対流熱伝 達率、日本建築学会大会学術講演会梗概集、pp387-388、1999.9

12) 尾関義一ほか 2 名：複雑な内部形状を有するメッシュ対応型放射伝熟 計算手法に関する研究、空気調和・衛生工学会論文集、No.62、pp101-110、 1996.7

13）桑原浩平ほか 3 名：人体に関する対流熟伝達率ーサーマルマネキンを 用いた中風速実験一、空気調和・衛星こう学会学術講演会講演論文集、 pp1309-1312、2000.9

14）市原真希ほか 3 名：サーマルマネキンを用いた立位・座位人体各部位 の放射・対流熱伝達率の測定、日本建築学会計画系論文集 No.501、 pp45-51、1997.11

15) ISO 7726 : Ergonomics of the thermal environment - Instruments for measuring physical quantities., 1998

16) S. Tanabe et al. : Evaluating Thermal Environments using a Thermal Manikin with Controlled surface skin temperature, ASHRAE Transaction, Vol.100, pp39-48, 1994

17）尾関義一ほか 3 名 : 数値計算による人体の有効放射面櫝の評価、日本 建築学会計画系論文集 No.525、pp45-51、1999.11

18) P.O Fanger : Thermal Comfort, Danish Technical Press, 1970

19) ASHRAE Fundamentals, Chapter3, 1997

20) ASHRAE Fundamentals, Chapter8, 1997

21) G.M. Rapp : Convective Heat Transfer and Convective Coefficients of Nude Man, Cylinders and Shheres at Low Air Velocities, ASHRAE Transaction, No.2264, pp75-87, 1973.

22) Y. Nishi, A.P. Gagge : Direct Evaluation of Convective Heat Transfer Coefficient by Naphthalene Sublimation, Journal of Applied Physiology, Vol.29, No.6, pp830-838, 1970.12

23) 石垣秀圭ほか 8 名：人体の対流熱伝達率に関する実験的研究、人間一 生活環境系国際会議、pp279-282、1991

24) M. Nielsen, L. Pedersen : Studies on the heat loss by radiation and convection from clothed human body, Acta phys. Scandinav, Vol.27, pp272-294, 1952

25) D. Mitchell : Convective heat loss from man and other animals, in heat loss from animals and man, Butterworth, London, 1974

26) 梁禎訓ほか 4 名：実験及び数值サーマルマネキンを用いた人体の対流 熱伝達率の同定 (その 2) 屋外・室内環境における人体各部位の対流熱 伝達率の測定、空気調和・衛生工学会学術講演論文集、pp777-780、2001.9

27) 梁禎訓ほか 3 名: 実験及び数值サーマルマネキンを用いた人体の対流 熱伝達率の同定（その3）姿勢や家具配圈が人体各部位の対流熱伝達率 に及ぼす影響、日本建築学会大会学術講演会梗概集、pp425-426、2002.9

28) 社団法人空気調和・衛生工学会 : 快適な温熱環境のメカニズム 豊か な生活空間をめざして、社団法人空気調和・衛生工学会、1997.

(2004年 1 月 9 日原稿受理, 2004 年 6 月 23 日採用決定) 